\title{
Bayesian estimation of the diagnostic accuracy of a multiplex real-time PCR assay and bacteriological culture for 4 common bovine intramammary pathogens
}

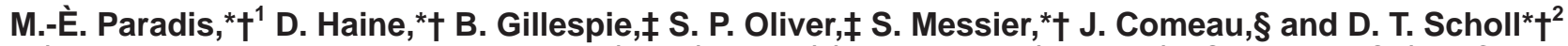 \\ *Département de pathologie et microbiologie, Faculté de Médecine Vétérinaire, Université de Montréal, St-Hyacinthe, Québec, Canada, \\ C.P. 5000 , J2S 7 C6 \\ †Canadian Bovine Mastitis Research Network, C. P. 5000, Saint-Hyacinthe, Québec, Canada, J2S 7C6 \\ ‡Department of Animal Science, University of Tennessee, 2640 Morgan Circle, Knoxville 37996 \\ §Département des mathématiques, Faculté des Sciences, Université de Sherbrooke, 2500 boulevard de l'Université, Sherbrooke, Québec, \\ Canada, J1K 2R1
}

\section{ABSTRACT}

Bacteriological culture $(\mathrm{BC})$ is the traditional method for intramammary infection diagnosis but lacks sensitivity and is time consuming. Multiplex real-time PCR (mr-PCR) enables testing the presence of several bacteria and reduces diagnosis time. Our objective was to estimate bacterial species-specific sensitivity (Se) and specificity of both BC and mr-PCR tests for detecting bacteria in milk samples from clinical mastitis cases and from apparently normal quarters, using a Bayesian latent class model. Milk samples from 1,014 clinical mastitis cases and 1,495 samples from apparently normal quarters were analyzed by $\mathrm{BC}$ and $\mathrm{mr}-\mathrm{PCR}$. Two positive culture definitions were used: $\geq 1 \mathrm{cfu} / 0.01$ $\mathrm{mL}$ and $\geq 10 \mathrm{cfu} / 0.01 \mathrm{~mL}$ of the specified bacteria. The mr-PCR was designed to simultaneously detect Staphylococcus aureus, Streptococcus uberis, Escherichia coli, and Streptococcus agalactiae. The priors used in our Bayesian model were weakly informative, with BC priors using the best available error data. Results were compared with those obtained using uniform priors for mr-PCR to test robustness. Weak and uniform priors gave about the same posterior distributions except for Strep. uberis from normal quarters and Strep. agalactiae. Multiplex real-time PCR Se on milk from clinical mastitis were lower than mr-PCR Se on milk from normal quarters. Multiplex real-time PCR Se was higher than BC on milk from normal quarters. Multiplex realtime PCR Se was generally lower than BC on milk from clinical mastitis and it varied by clinical severity.

Received January 9, 2012.

Accepted July 9, 2012.

${ }^{1}$ Corresponding author: marieparadis@hotmail.com

${ }^{2}$ Present address: South Dakota State University, Box 2207, Brookings, SD 57007.
The estimate specificities of detection for all pathogens were $\geq 99 \%$, regardless of sample type. The effect of milk sample preservation before testing was evaluated and may have been a factor that affected our observed results. A significant association was observed between sample age and mr-PCR results leading to reduced detection of E. coli and Strep. agalactiae in nonclinical samples. Differences in sample age between conduct of $\mathrm{BC}$ and of mr-PCR did not concur with any apparent differences between Se estimates of the 2 tests. Further work should be done to extend these results to other PCR-based tests for detecting bacterial species in milk samples, for which presented results could be used as prior parameter distributions. Limits of sample handling and storage and the potential existence of substances in clinical case samples that may interfere with PCR reactions also are worth further investigation.

Key words: mastitis, bacterial culture, real-time polymerase chain reaction, latent class model

\section{INTRODUCTION}

Successful pathogen-specific mastitis research and implementation of effective farm-level mastitis control programs rely on accurate and timely diagnosis of clinical and nonclinical IMI. Bacteriological culture is a method in widespread use, but this testing method could lack sensitivity (Se), as a large proportion of milk samples taken from clinical or subclinical mastitis cases show no growth in conventional culture (Makovec and Ruegg, 2003; Olde Riekerink et al., 2008; Taponen et al., 2009). For example, a negative culture may result from low numbers of bacteria in the sample (Sears et al. 1990). Bacteriological culture requires incubation time and distinguishing definitively between morphologically similar pathogens may require subculture and biochemical testing and, hence, additional materials, labor, and time (Hogan et al., 1999). 
The financial advantages of mastitis diagnosis tools that provide better diagnostic properties for the cost are obvious. Therefore, interest is increasing in the use of PCR technology to diagnose IMI in dairy cows (Viguier et al., 2009). Of special interest are multiplex real-time PCR (mr-PCR) assays, which enable simultaneous testing for the presence of several different bacterial species in milk samples. The technology works by detecting the unique DNA composition of specific mastitis-causing bacteria in milk samples. Several mrPCR assays are commercially available and several more are likely to be offered in the coming years. However, despite the potential attractiveness of possibly greater diagnostic Se and specificity $(\mathbf{S p})$, as well as potential reduced time to diagnosis, routinely using this technology is not yet advised. Prior to use in the field, the assay's false negative $(1-\mathrm{Se})$ and false positive $(1-\mathrm{Sp})$ rates need to be well estimated to avoid a substantial risk of erroneous farm-level decision making and subsequent failure to optimize udder health on the farm.

Direct calculation of the Se and Sp values presumes perfect knowledge of the true infection state of all tested samples. The limitations of bacteriological culture of milk samples render it imperfect as a true gold standard, despite its practical recognition as the reference method of choice (National Mastitis Council, 2004). To circumvent the problem of an imperfect gold standard, Bayesian latent class modeling can be used (Dohoo et al., 2009). Such a model uses the results of multiple tests applied to all samples to estimate the unknown (or latent) true infection state of each sample and, hence, the error rates for all tests simultaneously, without assuming any to be a perfect reference standard. Bayesian methods work through Bayes Theorem, which states that posterior distributions summarizing final conclusions are the product of prior information (summarizing predata knowledge) and the likelihood function, containing the information in the current data set. Through the use of prior information, Bayesian analysis can estimate more parameters than there are degrees of freedom in the data, which can be an advantage in diagnostic testing situations in which no perfect reference standards exist. This advantage comes at the cost of having to specify prior distributions, upon which the final conclusions may depend.

The National Cohort of Dairy Farms (NCDF) assembled by the Canadian Bovine Mastitis Research Network (CBMRN; Saint-Hyacinthe, QC, Canada) provides a well-defined Canadian dairy population (Reyher et al., 2011) in which to estimate the diagnostic accuracy of a recently developed mr-PCR assay that targets some of the common pathogens implicated in
IMI: Staphylococcus aureus, Streptococcus uberis, Escherichia coli, and Streptococcus agalactiae. Although Strep. agalactiae has become very uncommon, it is still quite important to recognize this pathogen when it is present to arrest its transmission as rapidly as possible (Keefe, 1997).

The aim of this research was to estimate, through Bayesian modeling, the bacterial species-specific Se (proportion of real bacterial species-specific infected quarters that test positive) and Sp (proportion of real bacterial species-specific uninfected quarters that test negative) values of both traditional bacteriological culture and an mr-PCR test as applied to clinical mastitis milk samples and in large-scale IMI screening samples.

\section{MATERIALS AND METHODS}

\section{Data Sources}

Quarter milk samples from 1,701 clinical mastitis cases (clinical samples) were acquired from all farms in the CBMRN Core Research Platform's NCDF through the Mastitis Laboratory Network (MLN; Reyher et al., 2011). These samples represent a census of the clinical cases identified during the 2007 data collection year of the NCDF. Also, 4,000 randomly selected mammary quarter milk samples that originate from randomly selected lactating cows and cows before dry-off and after calving that were all apparently not experiencing clinical mastitis (nonclinical samples) were acquired in the NCDF 2008 IMI sampling series.

The NCDF comprises 91 commercial dairy farms in 6 provinces sampled over a 2-yr period. Research centers in Alberta, Ontario, Quebec, and the Maritime provinces (Prince Edward Island, Nova Scotia, and New Brunswick) were established by regional directors of the CBMRN (Reyher et al., 2011). The NCDF farms were primarily Holstein-Friesian herds participating in DHI milk recording and were selected to achieve a uniform distribution among 3 strata of bulk tank SCC and to reflect their respective provinces' proportions of freestall housing systems.

Standardized protocols were implemented for milk samplings, sample handling, and data collection (protocols available upon request), and training of producers to follow protocols. For clinical cases of mastitis, farmers were asked to sample cows they identified as having abnormal milk or more severe clinical signs. Single samples of the affected quarter were taken on the day of diagnosis, and repeated at 2 to 3 and at 4 to 5 wk after diagnosis. Milk samples for detecting bacteria in the milk of apparently normal cows were obtained from the longitudinal incidence-density sampling series 
described in Reyher et al. (2011). The sampling was directed at lactating cows with no abnormal milk at the beginning of the series. These samples were taken by trained research technicians. Fifteen cows were enrolled for 4 separate time periods throughout the $2 \mathrm{yr}$.

Milk samples taken by farm personnel were frozen and stored on the farm until monthly pickup by technicians. Samples taken by technicians were placed on ice and subsequently frozen for storage at $-20^{\circ} \mathrm{C}$. Samples were submitted to 1 of 4 milk bacteriology laboratories comprising the MLN. The MLN represents coordinated regional mastitis bacteriology laboratories using standardized procedures in which bacteriological culture and species identification was developed based on National Mastitis Council guidelines (Hogan et al., 1999). For details on milk sample processing, please see NCDF (2009). After bacterial identification, 2-mL aliquots of all clinical case samples were placed into 2 sterile 2.0-mL CryoVials (Nalgene no. 5012-0020; Nalgene, Rochester, NY), frozen, and shipped on ice by overnight courier to the CBMRN central laboratory and stored at $-80^{\circ} \mathrm{C}$ for later use for mr-PCR testing. Samples from nonclinical mammary quarters were selected systematically as every eighth sample received by each laboratory and were handled in the same manner as clinical case samples. All bacteriological data were stored in a relational database (Access 2003; Microsoft Corp., Redmond, Washington). For more details. please refer to Reyher et al. (2011).

Each of the 1,701 clinical and 4,000 nonclinical samples previously stored in CryoVials were transferred to the collaborating laboratory of Steve Oliver at The University of Tennessee (Knoxville) for identification of bacteria by the mr-PCR assay developed in his laboratory. The assay was designed to simultaneously detect 4 mastitis pathogens in bovine milk: Staph. aureus, Strep. uberis, E. coli, and Strep. agalactiae. However, among the 4,000 nonclinical samples, only 1,500 were tested by $\mathrm{mr}-\mathrm{PCR}$, as the estimated prevalence of mr-PCRpositive samples was low and simulation of Bayesian estimations with greater sample sizes indicated that very little additional precision of estimates would be obtained by continuing to analyze nonclinical samples. Consequently, the tested nonclinical samples only originated from Alberta and Ontario regions because of systematic region testing order. The mr-PCR bacterial identification data were linked to the CBMRN NCDF bacterial culture data for Se and Sp estimation.

Finally, culture and mr-PCR results from clinical milk samples that were not harvested the day of diagnosis, but 2 to 5 wk after diagnosis, were excluded from this study $(\mathrm{n}=612)$. Samples whose laboratory results sheets had codes indicating laboratory accidents, damaged samples, samples with a doubtful sample type, and samples with doubtful identification numbers were also eliminated from analysis $(\mathrm{n}=84)$.

\section{DNA Isolation and mr-PCR}

Milk samples were enriched with Trypticase soy broth (Becton Dickinson and Co., Franklin Lakes, NJ) and incubated for 16 to $18 \mathrm{~h}$ at $37^{\circ} \mathrm{C}$. After overnight enrichment, bacterial DNA was isolated directly from milk following the method described by Gillespie and Oliver (2005). American Type Culture Collection (ATCC, Manassas, VA) reference strains used as positive controls for the mr-PCR assay included Staph. aureus (ATCC 10832), Strep. uberis (ATCC 27958), E. coli (ATCC 25922), and Strep. agalactiae (ATCC 27956). Controls for the real-time PCR assay were prepared by inoculating UHT milk with 1 of the 4 ATCC control strains and performing DNA isolation as described by Gillespie and Oliver (2005). The mr-PCR developed in the Oliver laboratory targets the following genes: nuc gene for Staph. aureus, plasminogen activator gene for Strep. uberis, wec A gene for E. coli, and cfb gene encoding the Christie-Atkins-Munch-Petersen (CAMP) factor for Strep. agalactiae. Primers and dual-labeled probes for detection of Strep. uberis and Strep. agalactiae were as described by Gillespie and Oliver (2005). Primers and dual-labeled probes for Staph. aureus targeted the nuc gene based on primers used by Brakstad et al. (1992), and for E. coli the wec A gene based on primers used by Bayardelle and Zafarullah (2002). Primers and dual-labeled probes were purchased from Integrated DNA Technologies Inc. (IDT, Coralville, IA). The real-time PCR was preformed as described by Gillespie and Oliver (2005) with modifications. Each real-time PCR run was performed in the iQ5 real-time PCR instrument (Bio-Rad Laboratories Inc., Hercules, CA). Samples were run in a 96-well plate in triplicate. Each 96-well plate contained, in triplicate, a nontemplate control, Staph. aureus-, Strep. uberis-, E. coli-, and Strep. agalactiae-positive controls. A total of 27 milk samples were run in triplicate on each plate. Milk samples were considered positive or negative based on their threshold cycle $(\mathbf{C t})$ value. The $\mathrm{Ct}$ is defined as the cycle number at which the fluorescence passes the threshold baseline. The $\mathrm{Ct}$ value determines if a sample is negative or positive based on the values of the positive controls and the nontemplate control. The negative cut-off $\mathrm{Ct}$ value was based on the average of the negative control $\mathrm{Ct}$ values and the negative sample $\mathrm{Ct}$ values. The average $\mathrm{Ct}$ value of this minus 1 standard deviation was used to establish the negative and positive values. The negative threshold values for Staph. aureus, Strep. uberis, E. coli, and Strep. agalactiae were $28.61,28.33,29.55$, and 21.52 , respectively. 


\section{Bayesian Estimation of Se and Sp of Bacterial Culture and $m r-P C R$}

To estimate the Se and the Sp of both assay methods for each of the 4 specific bacterial species, we used the Bayesian latent class model developed by Joseph et al. (1995) applied to conditionally dependent tests (Dendukuri and Joseph, 2001). The model was implemented in the JAGS 2.2.0 program (Plummer, 2003) called through R 2.13.0 software (R Development Core Team, 2009) using the rjags package. A separate model was fit for each of the 8 combinations of sample type (clinical quarter or nonclinical quarter) and 4 bacterial species. Additional models were fit to explore the effects of certain subgroupings on Se and Sp estimates. Aside from the data, which consist of the cross-classification of results from the 2 tests, the model requires prior inputs for the 5 unknown parameters, including the prevalence of the bacterial species under study and the Se and Sp of each test. The a priori information, referred to as priors, was entered as $\beta$ density functions, as is standard for binomial parameters (Joseph et al., 1995).

To create prior distributions for the Se and Sp of bacteriological culture for Staph. aureus, Strep. uberis and E. coli Se and Sp, the recent study by Dohoo et al. (2011) was used. Dohoo et al. (2011) estimated both the Se and Sp of a variety of definitions of IMI-based results from a single milk sample by using pseudo gold standard consensus-based IMI definitions obtained from a set of triplicate samples that had been taken at 1-wk intervals. Prior information for Strep. agalactiae came from Dinsmore et al. (1991), which is the most recent published work on the accuracy of cultures of single samples for the diagnosis of Strep. agalactiae IMI. Please refer to Table 1 to see all prior information used.

Several publications have reported some speciesspecific Se and Sp mr-PCR assay estimates on milk samples harvested from the field (Phuektes et al., 2001; Gillespie and Oliver, 2005; Koskinen et al., 2010; Wellenberg et al., 2010). However, in all these publications, the bacteriological culture was used as the gold standard for the calculations of the Se and Sp estimates, making these estimates potentially biased by the imperfect accuracy of bacteriological culture. Weak prior information were used for mr-PCR Se, captured with a $\beta(a, 1)$ prior distribution increasing monotically to a finite maximum of 1 . This distribution favors larger Se (i.e., vague prior judgment that the test is reasonably good, or a reluctant prior of seeing the test as perfect). From Gillespie and Oliver (2005) who used the same mr-PCR as in this study, we determined the $\beta$ distributions with a median set at $92 \%$ for all species except for E. coli. For E. coli, having no reference, we based our $\beta$ distribution on the bacterial culture and, using

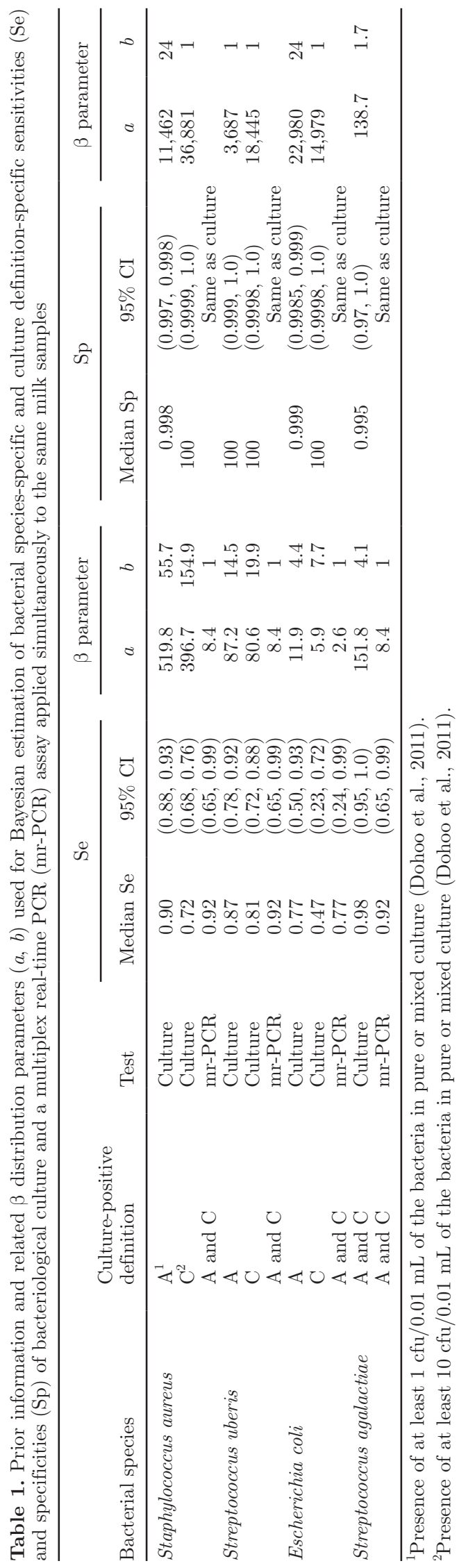

Journal of Dairy Science Vol. 95 No. 11, 2012 
the same approach, set the median at the same level of $77 \%$. All prevalence priors had a flat $\beta$ distribution with parameters $(1,1)$. Prior Se, Sp, and prevalence $\beta$ distributions were estimated using BetaBuster (http:// www.epi.ucdavis.edu/diagnostictests/betabuster.html).

To assess the effect of prior information on the posterior distributions, each model was estimated, but with uniform priors $[\beta(1,1)]$ for Se substituted for the above-described priors. The goal was to have posteriors that were not dependent on the exact functional form of the priors, the analysis being robust to the choice of priors (Albert, 2009). Also, the random number generator of Wichmann and Hill (1983) was specified as starting seed for each chain. To improve convergence and get more precise estimates of the posterior distribution, 2 Markov chain Monte Carlo chains were run with different starting values (Gelman and Rubin, 1992). For each chain, after a burn-in phase of 2,000 iterations, 50,000 iterations were monitored with a thinning of 1 in 10. If any convergence problems were identified with trace plot, autocorrelation plot, Gelman-Rubin test or Geweke's convergence diagnostic test, 50,000 additional iterations were monitored for each chain with a thinning of 1 in 25 .

To see if the use of a different definition of positive diagnostic for culture has an effect on Se and Sp estimates, 2 definitions already considered in Dohoo et al. (2011) were evaluated: presence of at least $1 \mathrm{cfu} / 0.01$ $\mathrm{mL}$ of the bacteria (culture definition A in Dohoo et al., 2011) or presence of at least $10 \mathrm{cfu} / 0.01 \mathrm{~mL}$ (definition C) in pure or mixed culture. Samples that had more than 2 bacterial species present according to the mrPCR test or in culture were considered contaminated and excluded from analyses, except in the calculations for Staph. aureus and Strep. agalactiae, as in Reyher et al. (2011).

The quarters having clinical symptoms were given a severity score between 1 and 3 at the time of sampling by the person performing the sampling (Sears and McCarthy, 2003). Subgroups mild, moderate, and severe consisted of cows with abnormal milk only, cows with abnormal milk with swollen quarter, and cows with abnormal milk, swollen quarter, and systemic symptoms, respectively. Estimates of Se and Sp were made within each of these subgroups separately to explore potential associations of Se and Sp of bacterial culture and $\mathrm{mr}-$ PCR with mastitis severity.

\section{Effect of Sample Age on mr-PCR Performance}

The effect of the number of days from sample harvest to the performance of mr-PCR was evaluated by crosstabulating mr-PCR pathogen-specific results (positive or negative) versus total time (d) between the date the sample was harvested and the date the sample was tested by mr-PCR (clinical case samples: $<450,450-549$, and 550 positive days; nonclinical samples: $<250,250-349$, and 350 positive days) and a $\chi^{2}$ (or Fisher exact) test was performed. The effect of sample age on the odds of a positive mr-PCR test of a pathogen was evaluated using generalized linear mixed models for a binomial family with a logit link in which sample age was put on a continuous scale, and region and season of sampling were also included as well as a random effect for herd. Parameter estimates were obtained by minimizing the Laplacian approximation to the deviance function with the lme4 package in $\mathrm{R}$ (Bates and al., 2011). Interaction terms between sample age and region were evaluated but no consistent regional patterns were observed. For practicality, therefore, only models without interactions are presented. The assumption of linearity of sample age effect was verified by dividing sample age into 4 categories that were roughly equal-sized and modeled in the form of indicator variables. The log odds of a positive mr-PCR test for each pathogen among the observations that fall in each of the 4 categories was computed and those values were plotted against the midpoints of the categories.

\section{Effect of Intertest Time Interval}

The time lapse between culture and mr-PCR tests was calculated by counting the number of days between the date the sample was cultured and the date the sample was analyzed by mr-PCR. To verify that the time difference was not associated with pathogen-specific discordant results between bacteriological culture and mr-PCR assay, for each type of sample and pathogen, the odds ratios of time difference on the risk of $\mathrm{mr}$ PCR positive results among specific pathogen-negative cultures and specific types of samples were estimated using the same approach as above, with generalized linear mixed models in which time difference was put on a continuous scale, including region and season of sampling and random effects for herd.

\section{RESULTS}

\section{Descriptive Data}

In total, 1,013 clinical milks samples and 1,492 nonclinical samples were analyzed by both bacteriological culture and mr-PCR. The clinical samples were collected between January 31, 2007, and October 18, 2007. They were cultured between February 19, 2007, and November 6, 2007, and mr-PCR tested between January 17, 2008, and February 2, 2009. The nonclinical samples were collected between January 16, 2008, and 
October 9, 2008. They were cultured between June 21, 2008, and December 2, 2008, and mr-PCR tested between February 12, 2009, and June 8, 2009.

The clinical milk samples came from 88 herds and the nonclinical milk samples came from 37 herds. Among the 88 herds from which clinical samples were collected, 16, 26, 28, and 18 herds were from Alberta, Ontario, Quebec, and Atlantic regions, respectively. Among the 37 herds from which nonclinical samples were taken, 14 and 23 herds were from Alberta and Ontario regions, respectively. Two hundred four, 343, 213, and 254 clinical samples collected from Alberta, Ontario, Quebec, and Atlantic regions, respectively. Five hundred fourteen and 981 nonclinical samples harvested from Alberta and Ontario regions, respectively. A median of $10(\mathrm{SD}=8.9)$ clinical samples and 36 $(\mathrm{SD}=15.7)$ nonclinical samples were taken per herd. Among the nonclinical samples, 385, 454, and 305 were the first, second, and third respective sequential intensive incidence-density samples from lactating cows, in either of 2 intensive sampling periods of 2008; 178 and 165 samples were collected between 4 and 2 wk before dry-off and between 2 wk and dry-off, respectively; 8 samples were taken within 2 wk after calving.

The bacterial culture and mr-PCR results for clinical and nonclinical samples are cross-classified in Table 2. Among clinical samples, the greater prevalence and bias corrected $\kappa$ coefficient of agreement between culture and mr-PCR results was seen for Strep. agalactiae detection (>99\%), followed by Strep. uberis ( $94 \%)$ and Staph. aureus ( $\sim 91 \%)$. The least agreement was seen for E. coli detection ( $85 \%)$. Among nonclinical samples, the agreement between culture and mr-PCR tests for E. coli, Strep. uberis, or Strep. agalactiae detection was quite similar (between 98 and 99\%). The least agreement was seen for Staph. aureus detection ( $95 \%)$. According to bacterial culture results, 191 subclinical samples showed greater than 2 species (contaminated samples). Among these 191 samples, 3 were positive for E. coli and one was positive for Strep. uberis at mr-PCR testing. According to mr-PCR results, only 1 subclinical sample showed greater than 2 species, and this sample showed $10 \mathrm{cfu} / 0.01 \mathrm{~mL}$ of Staph. aureus at culture. Relating to clinical samples, 98 of these showed greater than 2 species at culture. Among these 98 samples, 12 were positive to $E$. coli and 11 were positive for Strep. uberis at mr-PCR testing. According to mr-PCR results, 3 clinical samples showed greater than 2 species. At culture, 2 of these 3 samples were negative and the other sample had Staph. aureus growing.

\section{Se and Sp Estimates}

Tables 3, 4, 5, and 6 present the posterior medians obtained with their 95\% Bayesian credible intervals (BCI) for the estimated Se of mr-PCR and bacteriological culture using definitions $\mathrm{A}$ and $\mathrm{C}$ on clinical and nonclinical sample types to detect each of the 4 pathogens. For detecting Staph. aureus in milk samples from nonclinical quarters using culture-positive defini-

Table 2. Cross-classification of results of bacteriological culture and a multiplex real-time PCR (mr-PCR) for detecting bacteria in mammary quarter milk samples from farmer-identified clinical mastitis cases (clinical) and from randomly selected lactating cows that were apparently not experiencing clinical mastitis (nonclinical)

\begin{tabular}{|c|c|c|c|c|c|c|}
\hline \multirow[b]{3}{*}{ Bacterial species } & \multirow{3}{*}{$\begin{array}{c}\text { Culture positive } \\
\text { definition } \\
\text { (cfu/0.01 mL) }\end{array}$} & \multirow{3}{*}{$\begin{array}{l}\text { Culture } \\
\text { result }\end{array}$} & \multicolumn{4}{|c|}{ mr-PCR result } \\
\hline & & & \multicolumn{2}{|c|}{ Clinical } & \multicolumn{2}{|c|}{ Nonclinical } \\
\hline & & & + & - & + & - \\
\hline \multirow[t]{4}{*}{ Staphylococcus aureus } & 1 & + & 95 & 41 & 36 & 13 \\
\hline & & - & 46 & 831 & 69 & 1,374 \\
\hline & 10 & + & 84 & 37 & 31 & 6 \\
\hline & & - & 57 & 835 & 74 & 1,381 \\
\hline \multirow[t]{4}{*}{ Streptococcus uberis ${ }^{2}$} & 1 & + & 32 & 21 & 1 & 0 \\
\hline & & - & 34 & 825 & 11 & 1,288 \\
\hline & 10 & + & 30 & 20 & 1 & 0 \\
\hline & & - & 36 & 826 & 11 & 1,288 \\
\hline \multirow[t]{4}{*}{ Escherichia coli $^{2}$} & 1 & + & 64 & 84 & 0 & 4 \\
\hline & & - & 62 & 702 & 20 & 1,276 \\
\hline & 10 & + & 50 & 49 & 0 & 0 \\
\hline & & - & 76 & 737 & 20 & 1,280 \\
\hline \multirow{2}{*}{ Streptococcus agalactiae } & $\mathrm{NA}^{3}$ & + & 0 & 0 & 0 & 0 \\
\hline & & - & 1 & 1,012 & 12 & 1,480 \\
\hline
\end{tabular}

${ }^{1}$ As in Dohoo et al. (2011).

${ }^{2}$ Calculations for Strep. uberis and E. coli excluded samples with greater than 2 species identified by culture or mr-PCR.

${ }^{3}$ No culture growth was observed for Strep. agalactiae. 
tion A, the Se of mr-PCR was slightly higher than for culture, but with overlapping BCI (Table 3). The same was true when culture was interpreted by definition $\mathrm{C}$, but the BCI did not overlap (Table 4). On clinical-case samples, bacterial culture interpreted with definition A had higher Se than mr-PCR (Table 3), whereas culture and mr-PCR Se were equivalent when culture was interpreted by definition C (Table 4). Within all 3 clinical mastitis severity levels, bacterial culture interpreted with definition A was mostly more sensitive than mrPCR (Table 5), whereas when culture was interpreted with definition $\mathrm{C}$, culture Se was lower than mr-PCR, but with overlapping credibility intervals in all clinical mastitis severity levels (Table 6).

For detecting Strep. uberis in milk samples, the estimated Se of bacterial culture was not different from the estimated Se of mr-PCR. This was true for samples from nonclinical or clinical mammary quarters, and for bacterial culture interpreted by definition A or definition C. As with Staph. aureus detection, the culture definition influenced the estimated Se of bacterial culture, as is expected, but had no apparent association with the estimated Se of mr-PCR.

With respect to detecting E. coli in nonclinical milk samples, the estimated Se of mr-PCR was substantially higher than that of bacterial culture, with no overlap of BCI (Table 3). For detecting E. coli in samples from clinical-case quarters, bacteriological culture-estimated Se was higher than mr-PCR-estimated Se, but the BCI were also overlapping (Table 3). For moderate and severe clinical-case samples, the estimated Se of bacterial culture was substantially higher than the estimated Se of mr-PCR (Table 5), but these differences disappeared when bacterial culture was interpreted by definition C (Table 6). As with Staph aureus and Strep. uberis detection, the culture definition influenced the estimated Se of bacterial culture, as is expected, but had no apparent association with the estimated Se of mr-PCR.

With respect to Strep. agalactiae, differences in estimated Se relative to using mr-PCR or bacterial culture were not apparent. Estimates were essentially equivalent to prior values, which is a function of the small number of Strep. agalactiae-positive observations.

The Sp estimates, when using culture definition A or C, Staph. aureus, Strep. uberis, and E. coli, were all $\geq 99.7 \%$ with a $95 \%$ BCI $<0.3 \%$, whatever the sample type. Because no culture growth occurred for Strep. agalactiae, the culture definitions were equivalent and Sp estimates were $\geq 99.1 \%$ with a $95 \%$ BCI $<1 \%$.

\section{Association of Sample Age with mr-PCR Se}

No associations were observed between sample age and the frequency of positive mr-PCR results on clini-

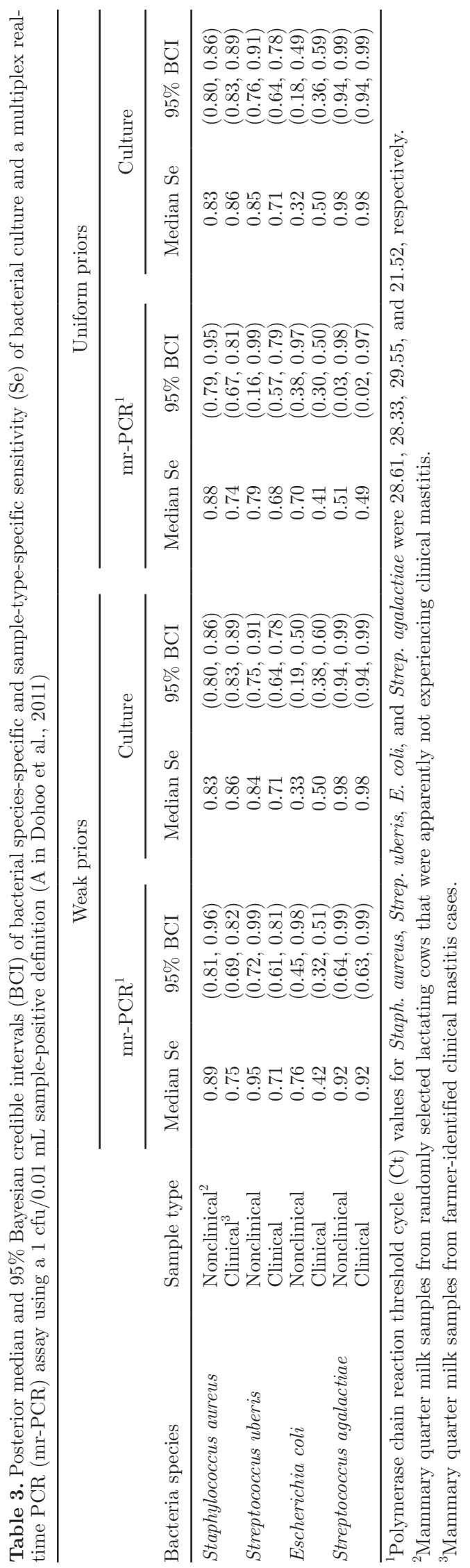


cal-case samples for Staph. aureus, Strep. uberis, or E. coli (too few observations for Strep. agalactiae). However, in samples from nonclinical quarters, an association existed between the number of samples with positive mr-PCR results for E. coli and Strep. agalactiae and sample age, but not for Staph. aureus and Strep. uberis (95\% CI $0.02-0.47,0.00-0.23,0.47-1.51$, and $0.16-4.3$ respectively; Table 7). Herd-level variances averaged $0.58(0.21-1.01)$.

\section{Association of Intertest Time Interval with Culture and $m r-P C R$ Results}

The estimated odds ratios of a positive mr-PCR per day of intertest interval duration among culture negative samples are given in Table 8 . No differences were seen for any species except for Strep. agalactiae from nonclinical-case quarters for which the odds were higher to get a negative mr-PCR result given increasing intertest interval.

\section{DISCUSSION}

\section{Culture and mr-PCR Comparative Se and Sp}

The mr-PCR technology is more expensive than bacteriological culture. For example, the mr-PCR test used in this study cost around 3 times the price of the culture, besides the mr-PCR instrument and computer. On the other hand, bacteriological culture and identification of bacteria by standard biochemical methods often necessitate more than $48 \mathrm{~h}$ to complete, which is not the case with PCR technology, and can be limited by lack of sensitivity, slow-growing or poorly viable organisms, and antimicrobial therapy. A school of thought exists that PCR technology offers potential milk bacteriology diagnostics that are likely to be at least as sensitive as or more sensitive than bacteriological milk culture and more specific. A recent study showed that in approximately half of the clinical mastitis cases in which conventional culture failed to detect bacteria, a mrPCR test detected mastitis pathogens, often in large quantities (Taponen et al., 2009).

In the present study, the mr-PCR assay tested had estimated Se and $\mathrm{Sp}$ values for Staph. aureus, Strep. uberis, E. coli, and Strep. agalactiae detection in milk that were often equal to and sometimes higher than with bacteriological culture. On the other hand, the estimated Se of the tested mr-PCR for detecting Staph. aureus and $E$. coli in milk from quarters with moderate or severe clinical mastitis were lower than with bacteriological culture. Samples being older when mr-PCR was conducted than when cultured did not account for apparently lower Staph. aureus and E. coli mr-PCR Se 
Table 5. Posterior median and 95\% Bayesian credible intervals (BCI) of bacterial species-specific and clinical mastitis severity-specific sensitivity (Se) of bacterial culture and multiplex real-time (mr-PCR) assay using a $1 \mathrm{cfu} / 0.01 \mathrm{~mL}$ culture-positive definition (Dohoo et al., 2011)

\begin{tabular}{|c|c|c|c|c|c|}
\hline \multirow[b]{2}{*}{ Bacteria species } & \multirow[b]{2}{*}{ Sample type } & \multicolumn{2}{|c|}{ mr-PCR ${ }^{1}$} & \multicolumn{2}{|c|}{ Culture } \\
\hline & & Median Se & $95 \%$ BCI & Median Se & $95 \%$ BCI \\
\hline Staphylococcus aureus & Severe mastitis ${ }^{4}$ & 0.72 & $(0.54,0.86)$ & 0.89 & $(0.87,0.92)$ \\
\hline \multirow[t]{2}{*}{ Streptococcus uberis } & Mild mastitis & 0.71 & $(0.57,0.83)$ & 0.80 & $(0.72,0.86)$ \\
\hline & Moderate mastitis & 0.84 & $(0.70,0.94)$ & 0.78 & $(0.71,0.85)$ \\
\hline \multirow{2}{*}{ Escherichia coli } & Moderate mastitis & 0.39 & $(0.27,0.52)$ & 0.54 & $(0.39,0.67)$ \\
\hline & Severe mastitis & 0.42 & $(0.26,0.59)$ & 0.75 & $(0.54,0.89)$ \\
\hline \multirow{3}{*}{ Streptococcus agalactiae } & Mild mastitis & 0.92 & $(0.65,0.99)$ & 0.98 & $(0.94,0.99)$ \\
\hline & Moderate mastitis & 0.92 & $(0.65,0.99)$ & 0.98 & $(0.94,0.99)$ \\
\hline & Severe mastitis & 0.92 & $(0.64,0.99)$ & 0.98 & $(0.94,0.99)$ \\
\hline
\end{tabular}

${ }^{1}$ Polymerase chain reaction threshold cycle (Ct) values for Staph. aureus, Strep. uberis, E. coli, and Strep. agalactiae were 28.61, 28.33, 29.55, and 21.52 , respectively.

${ }^{2}$ Abnormal milk only.

${ }^{3}$ Abnormal milk plus a swollen quarter.

${ }^{4}$ Abnormal milk, swollen quarter, and systemic illness.

(Table 8). A possible explanation is that substances that interfere with 1 or more steps of the mr-PCR assay, but not bacterial culture, are more prominent in milk samples from Staph. aureus and E. coli IMI with moderate or severe clinical signs. Organic and inorganic chemicals, detergents, antibiotics, enzymes, polysaccharides, fats, proteins, and bacterial debris have been reported as potential PCR inhibitors (Wilson, I. G., 1997). On the other hand, poor viability of or dead bacteria and the presence of antibiotics or disinfectants in milk can also lead to a no-growth culture.

The Se results, but not the Sp results, of mr-PCR and bacteriological culture for detecting bacteria in mammary quarter milk samples were generally different between clinical and nonclinical samples. Because generally insufficient Strep. agalactiae detection events occurred, Strep. agalactiae detection is ignored in the following discussion. The mr-PCR assay seems to perform better in nonclinical samples than in clinical samples and, again, a possible explanation could be the presence of mr-PCR-inhibiting substances present in the abnormal milk associated with clinical mastitis.

Multiplex real-time PCR was substantially more sensitive than bacterial culture for detecting $E$. coli in samples from nonclinical mammary quarters. This was true despite the observation that sample age was associated with reduced mr-PCR detection of $E$. coli in this type of sample (Table 7). As results only from samples with $\leq 2$ different colony morphologies or bacterial species detected by both methods were modeled, taking

Table 6. Posterior median and 95\% Bayesian credible intervals (BCI) of bacterial species-specific and clinical mastitis severity-specific sensitivity (Se) of bacterial culture and multiplex real-time (mr-PCR) assay using a $10 \mathrm{cfu} / 0.01 \mathrm{~mL}$ culture-positive definition (Dohoo et al., 2011)

\begin{tabular}{|c|c|c|c|c|c|}
\hline Bacteria species & Sample type & \multicolumn{2}{|c|}{ mr-PCR ${ }^{1}$} & \multicolumn{2}{|c|}{ Culture } \\
\hline \multirow[t]{2}{*}{ Staphylococcus aureus } & Mild mastitis $^{2}$ & 0.92 & $(0.64,0.99)$ & 0.72 & $(0.68,0.76)$ \\
\hline & Severe mastitis ${ }^{4}$ & 0.91 & $(0.63,0.99)$ & 0.72 & $(0.68,0.76)$ \\
\hline \multirow[t]{2}{*}{ Streptococcus uberis } & Mild mastitis & 0.72 & $(0.57,0.84)$ & 0.74 & $(0.66,0.81)$ \\
\hline & Moderate mastitis & 0.84 & $(0.69,0.94)$ & 0.74 & $(0.66,0.81)$ \\
\hline & Moderate mastitis & 0.39 & $(0.23,0.55)$ & 0.34 & $(0.21,0.48)$ \\
\hline & Severe mastitis & 0.46 & $(0.25,0.70)$ & 0.54 & $(0.31,0.74)$ \\
\hline
\end{tabular}

${ }^{1}$ Polymerase chain reaction threshold cycle (Ct) values for Staph. aureus, Strep. uberis, E. coli, and Strep. agalactiae were 28.61, 28.33, 29.55, and 21.52 , respectively.

${ }^{2}$ Abnormal milk only.

${ }^{3}$ Abnormal milk plus a swollen quarter.

${ }^{4}$ Abnormal milk, swollen quarter, and systemic illness. 
Table 7. Odds ratios for a positive multiplex real-time PCR test if the duration of sample frozen storage was greater than $100 \mathrm{~d}$ versus $\leq 100 \mathrm{~d}$, estimated by sample type in multilevel models with region and season accounted for and herd as random effect

\begin{tabular}{|c|c|c|c|c|}
\hline \multirow[b]{2}{*}{ Pathogen } & \multicolumn{2}{|c|}{ Clinical samples ${ }^{1}$} & \multicolumn{2}{|c|}{ Nonclinical samples $^{2}$} \\
\hline & Odds ratio & $95 \% \mathrm{CI}$ & Odds ratio & $95 \% \mathrm{CI}$ \\
\hline Staphylococcus aureus & 1.46 & $(0.77,2.75)$ & 0.84 & $(0.47,1.51)$ \\
\hline \multicolumn{5}{|l|}{ Season } \\
\hline Winter & 1 & - & 1 & - \\
\hline Spring & 1.13 & $(0.42,3.07)$ & 1.84 & $(0.72,4.71)$ \\
\hline Summer & 0.98 & $(0.30,3.16)$ & 1.29 & $(0.36,4.57)$ \\
\hline Fall & 1.05 & $(0.22,4.97)$ & 2.55 & $(0.14,45.26)$ \\
\hline \multicolumn{5}{|l|}{ Region } \\
\hline West & 1 & - & 1 & - \\
\hline Ontario & 2.71 & $(1.30,5.63)$ & 0.77 & $(0.35,1.69)$ \\
\hline Quebec & 3.29 & $(1.42,7.63)$ & - & - \\
\hline Atlantic & 2.01 & $(0.89,4.53)$ & - & - \\
\hline Random effect: variance (SD) & \multicolumn{2}{|c|}{$0.22(0.47)$} & \multicolumn{2}{|c|}{$0.84(0.92)$} \\
\hline Streptococcus uberis & 0.69 & $(0.32,1.47)$ & 0.83 & $(0.16,4.30)$ \\
\hline \multicolumn{5}{|l|}{ Season } \\
\hline Winter & 1 & - & 1 & - \\
\hline Spring & 0.60 & $(0.20,1.80)$ & 0.41 & $(0.04,4.61)$ \\
\hline Summer & 0.26 & $(0.07,1.01)$ & 0.59 & $(0.02,15.17)$ \\
\hline Fall & 0.13 & $(0.02,1.05)$ & - & - \\
\hline \multicolumn{5}{|l|}{ Region } \\
\hline West & 1 & - & 1 & - \\
\hline Ontario & 0.96 & $(0.36,2.56)$ & 0.70 & $(0.22,2.24)$ \\
\hline Quebec & 0.83 & $(0.27,2.50)$ & - & - \\
\hline Atlantic & 1.06 & $(0.38,2.94)$ & - & - \\
\hline Random effect: variance (SD) & \multicolumn{2}{|c|}{$0.72(0.85)$} & \multicolumn{2}{|c|}{$0.18(0.42)$} \\
\hline Escherichia coli & 0.74 & $(0.41,1.33)$ & 0.08 & $(0.02,0.47)$ \\
\hline \multicolumn{5}{|l|}{ Season } \\
\hline Winter & 1 & - & 1 & - \\
\hline Spring & 0.36 & $(0.16,0.85)$ & 0.02 & $(0.00,0.22)$ \\
\hline Summer & 0.28 & $(0.10,0.77)$ & 0.00 & $(0.00,0.10)$ \\
\hline Fall & 0.11 & $(0.02,0.55)$ & 0.01 & $(0.00,1.75)$ \\
\hline \multicolumn{5}{|l|}{ Region } \\
\hline West & 1 & - & 1 & - \\
\hline Ontario & 1.64 & $(0.82,3.30)$ & 0.94 & $(0.30,3.02)$ \\
\hline Quebec & 1.53 & $(0.69,3.38)$ & - & - \\
\hline Atlantic & 1.67 & $(0.80,3.50)$ & - & - \\
\hline Random effect: variance (SD) & \multicolumn{2}{|c|}{$0.21(0.45)$} & \multicolumn{2}{|c|}{$0.91(0.95)$} \\
\hline Streptococcus agalactiae & & & 0.03 & $(0.00,0.23)$ \\
\hline \multicolumn{5}{|l|}{ Season } \\
\hline Winter & & & 1 & - \\
\hline Spring & & & 0.01 & $(0.00,0.26)$ \\
\hline Summer & & & 0.00 & $(0.00,0.24)$ \\
\hline Fall & & & - & - \\
\hline \multicolumn{5}{|l|}{ Region } \\
\hline \multicolumn{5}{|l|}{ West } \\
\hline \multicolumn{5}{|l|}{ Ontario } \\
\hline \multicolumn{5}{|l|}{ Quebec } \\
\hline \multicolumn{5}{|l|}{ Atlantic } \\
\hline Random effect: variance (SD) & & & & (.00) \\
\hline
\end{tabular}

${ }^{1}$ Mammary quarter milk samples from farmer-identified clinical mastitis cases.

${ }^{2}$ Mammary quarter milk samples from randomly selected lactating cows that were apparently not experiencing clinical mastitis.

mr-PCR E. coli positive as a diagnosis is less likely to represent a false-positive diagnosis. As expected, the use of a more restricted culture-positive definition lowered the estimated Se of culture, but the gain in Sp was negligible $(\leq 1 \%)$ making the use of a more restricted culture-positive definition less attractive. For detecting E. coli in milk from severe clinical infection cases, the
Se is higher with bacterial culture than with mr-PCR and is also higher than the Se of culture of samples from mild and moderate clinical cases. Whereas the Se estimates vary with degree of clinical severity and with bacterial species, the 95\% BCI overlap greatly, indicating that mastitis severity does not affect culture performances. 
Table 8. Estimated odds ratio and 95\% confidence interval of multiplex real-time PCR (mr-PCR)-positive versus mr-PCR-negative results per frozen storage time lapse means (d) between culture and mr-PCR tests among culture-negative samples

\begin{tabular}{|c|c|c|c|c|}
\hline \multirow[b]{2}{*}{ Bacterial species } & \multicolumn{2}{|c|}{ Clinical $^{1}$} & \multicolumn{2}{|c|}{ Nonclinical $^{2}$} \\
\hline & Odds ratio & $95 \%$ CI & Odds ratio & $95 \% \mathrm{CI}$ \\
\hline Staphylococcus aureus & 1.00 & $(0.99,1.01)$ & 1.00 & $(0.99,1.00)$ \\
\hline Streptococcus uberis & 1.00 & $(0.99,1.00)$ & 1.00 & $(0.99,1.01)$ \\
\hline Escherichia coli & 1.00 & $(1.00,1.01)$ & 1.00 & $(1.00,1.01)$ \\
\hline Streptococcus agalactiae & - & - & 0.97 & $(0.95,0.99)$ \\
\hline
\end{tabular}

The modification of the final $\mathrm{Ct}$ value used to distinguish between positive and negative results and its effect on estimated sensitivities and specificities has not been explored. The comparison of the Ct values against colony-forming-unit numbers appears to be very complex. The quantification of bacterial DNA is a clue to better interpret mr-PCR results and this aspect requires further study.

Errors in the specified prior parameter distributions would introduce error in the Bayesian Se estimates of both tests. Our current best knowledge, of course, is represented by the prior parameters and the observed cross-classification data. The prior Se and Sp estimates we used were derived from Dohoo et al. (2011) in which Se was estimated against the pseudo gold standard of consensus estimates of bacterial species-specific infection status (Andersen et al., 2010). These are suitable prior parameters for our bacterial culture test because they are recent, were derived within the same laboratories using the same protocols by which our culture results were obtained, and were obtained from the same longitudinal cohort of farms (although from a temporally independent sampling series; Reyher et al., 2011). Because no data are available to indicate that bacterial species-specific Se and Sp of bacterial culture of milk samples from clinical mastitis quarters differ from Se and Sp for culture of samples from nonclinical mastitis quarters, the estimates from Dohoo et al. (2011) represent the best available prior knowledge for clinicalcase Se and Sp of bacterial culture. To the authors' knowledge, all published reports of the Se and Sp of PCR-based methods in similar contexts are performed directly against bacterial culture. Clearly, these estimates would be biased for use in our context and, thus, unsuitable. We have no objective basis for assuming that definition A prior parameters are more valid than definition $\mathrm{C}$ prior parameters. We would simply assume that apparent and estimated Se of bacterial culture for the 4 targeted organisms is greater for definition A than the definition C. In the cases where the estimated
Se of mr-PCR also changed substantially when bacterial culture was interpreted by a different definition and with different priors, it was due to the mr-PCR results being more heavily dependent on priors than on observed cross-classified results of bacterial culture and mr-PCR. Such is the case when the proportion of test-positive results on the tests is not large.

Published data on prior information to be used with mr-PCR are very limited and always relying on a comparison with the bacterial culture as a gold standard. Therefore, a prior distribution reflecting this weak information on mr-PCR test performance was used. A prior distribution slowly increasing to a maximum of 1 represents our current knowledge that the test is reasonably good, with a reluctant prior of seeing the test as perfect. In comparison with uniform priors, the posterior results for the mr-PCR are consistent between the 2 prior distributions, except for Strep. uberis subclinical samples and Strep. agalactiae (for both definitions $\mathrm{A}$ and $\mathrm{C}$ ). In these cases, uniform priors gave much larger posterior distributions, which reflect the data sparseness of these situations. It should be noted, however, that E. coli subclinical samples also had few observations but no differences were seen between the 2 prior distributions used.

How should estimated Se $<1.0$ for both tests, when both tests have some positive results that are negative on the other test, be interpreted? Three types of errors are possibly operating that could produce discordant test results. The first is variation in the test results that is both random and independent between the tests. Independence of errors is confirmed by all dependence models being nondifferent $(<3 \%$ difference in estimated Se) from the corresponding independence models. The possible second error operating is unidentified characteristics of the 2 tests that are different between the 2 . These would include the biological bases for the tests, the methods and instrumentation used, and the criteria for interpreting the tests. It is these differences that we wish to explore and understand so as to develop 
strategies for choosing the best test for a given milk sample-testing context. The final general error possibly contributing to discordant nonpositive test results is differences in the handling of samples before each of the 2 tests. It is for this reason that estimations were made of the effects of sample age and of the difference in sample age between conduct of bacterial culture and mr-PCR.

\section{Freezing Effect}

Milk sample preservation before testing may have been a factor that affected our observed results, even if they do not seem to explain differences in estimated Se of the 2 laboratory methods that were studied. During CBMRN NCDF milk sample collection, due to shipping distances to regional bacteriology labs and the need to accommodate the laboratories' weekly sample analysis capacity, freezing of milk samples was necessary. A lot of milk samples taken by farm personnel were frozen and stored on the farm until monthly pickup by technicians. The quality of storage may have been affected, as samples frozen on farms are often placed in the freezer compartment of older refrigerator/freezer units in the milk house or barn. The freezers in these units often do not maintain a constant temperature and may go through frequent and extreme freeze-thaw cycles. Unfortunately, it was not possible to evaluate the effect of this issue on the culture and mr-PCR results. Unpublished data of K. Reyher (University of Prince Edward Island, PEI, Canada) made an analysis of frozen sample storage time that suggested reduced recovery by bacterial culture (all types of samples combined) of Staph. aureus, Strep. uberis, and E. coli when frozen sample storage time was over $100 \mathrm{~d}$. In the present study, the only significant associations of sample age and mr-PCR results were reduced detection of E. coli and Strep. agalactiae on nonclinical samples. Moreover, the difference in sample age between conduct of bacterial culture and of mr-PCR did not concord with any apparent differences between Se estimates of the 2 tests. On the contrary, estimated Se of mr-PCR for detecting Strep. agalactiae might have been higher than the corresponding bacterial culture Se estimates had the samples been closer in age at the time that the tests were conducted (Table 8).

These results should not be applied broadly to all PCR-based diagnostic tests. The various different PCR-based tests available for detecting bacterial species in milk samples may differ from one another in ways that affect test Se or Sp systematically or specifically for certain bacterial species or when applied to different types of samples. However, the results documented in the report may be very suitable as sources of prior parameter distributions for Bayesian estimation of Se and Sp characteristics of alternative PCR tests. Further work should also delineate in detail the effects of sample storage on performance of PCR-based approaches to detecting bacteria in milk samples.

\section{CONCLUSIONS}

The Sp of both bacterial culture and a mr-PCR assay for detecting Staph. aureus, Strep. uberis, E. coli, and Strep. agalactiae in milk samples from mammary quarters with clinical signs and mammary quarters with no clinical signs are very high. For detecting Staph. aureus, the Se ranged from about 0.66 to 0.96 , with bacterial culture being apparently superior in applications to samples from clinically affected quarters. For detecting Strep. uberis, the Se ranged from about 0.66 to 0.96 , with both tests being equivalent. This mr-PCR is not superior to bacterial culture for detecting $E$. coli from severe clinical cases, but it is in application to nonclinical samples. Further work should be done to extend these results to other PCR-based tests for detecting bacterial species in milk samples and to elucidate the limits of sample handling and storage and the potential existence of substances in clinical case samples that may interfere with PCR reactions.

\section{ACKNOWLEDGMENTS}

This research was financed by Natural Sciences and Engineering Research Council of Canada (Ottawa, ON, Canada), Alberta Milk (Edmonton, AB), Dairy Farmers of New Brunswick (Sussex, NB, Canada), Dairy Farmers of Nova Scotia (Lower Truro, NS, Canada), Dairy Farmers of Ontario (Mississauga, ON, Canada) and Dairy Farmers of Prince Edward Island (Charlottetown, PE, Canada), Novalait Inc. (Québec, QC, Canada), Dairy Farmers of Canada (Ottawa, ON, Canada), Canadian Dairy Network (Guelph, ON, Canada), Agriculture and Agri-Food Canada (Ottawa, ON, Canada), Public Health Agency of Canada (Ottawa, ON, Canada), Technology PEI Inc. (Charlottetown, PE, Canada), Université de Montréal (Montréal, QC, Canada) and University of Prince Edward Island (Charlottetown, PE, Canada) through the Canadian Bovine Mastitis Research Network (Saint-Hyacinthe, QC, Canada). The analysis of milk samples by mrPCR was conducted by the Tennessee Quality Milk Laboratory under the direction of Stephen P. Oliver at The University of Tennessee, (Knoxville). The authors thank Sasha Russel and Megan Maxwell (Department of Animal Science, The University of Tennessee, Knoxville) for their assistance with the multiplex real-time PCR. The authors thank Lawrence Joseph from McGill 
University (Montréal, QC, Canada) for his participation in Bayesian analysis.

\section{REFERENCES}

Albert, J. 2009. Bayesian Computation with R. 2nd ed. Springer, Dordrecht, the Netherlands, Heidelberg, Germany, London, UK, and New York, NY.

Andersen, S., I. R. Dohoo, R. Olde Riekerink, and H. Stryhn. 2010. Diagnosing intramammary infections: Evaluating expert opinions on the definition of intramammary infection using conjoint analysis. J. Dairy Sci. 93:2966-2975.

Bates, D., M. Maechler, and B. Bolker. 2011. The Comprehensive R Archive Network. Accessed Aug. 2011. http://cran.r-project.org/ web/packages/lme4/index.html.

Bayardelle, P., and M. Zafarullah. 2002. Development of oligonucleotide primers for the specific PCR-based detection of the most frequent Enterobacteriaceae species DNA using wec gene templates. Can. J. Microbiol. 48:113-122.

Brakstad, O. G., K. Aasbakk, and J. A. Maeland. 1992. Detection of Staphylococcus aureus by polymerase chain reaction amplification of the nuc gene. J. Clin. Microbiol. 30:1654-1660.

Dendukuri, N., and L. Joseph. 2001. Bayesian approaches to modeling the conditional dependence between multiple diagnostic tests. Biometrics 57:158-167.

Dinsmore, R. P., P. B. English, R. N. Gonzalez, P. M. Sears, and H. F. Schulte. 1991. Evaluation of methods for the diagnosis of Streptococcus agalactiae intramammary infections in dairy cattle. J Dairy Sci. 74:1521-1526.

Dohoo, I. R., S. W. Martin, and H. Stryhn. 2009. Veterinary Epidemiologic Research. 2nd ed. VER Inc., Charlottetown, PEI, Canada.

Dohoo, I. R., J. Smith, S. Andersen, D. F. Kelton, and S. Godden. 2011. Diagnosing intramammary infections: Evaluation of definitions based on a single milk sample. J. Dairy Sci. 94:250-261.

Gelman, A., and D. B. Rubin. 1992. Inference from iterative simulation using multiple sequences. Stat. Sci. 7:457-511.

Gillespie, B. E., and S. P. Oliver. 2005. Simultaneous detection of mastitis pathogens, Staphylococcus aureus, Streptococcus uberis, and Streptococcus agalactiae by multiplex real-time polymerase chain reaction. J. Dairy Sci. 88:3510-3518.

Hogan, J. S., R. N. Gonzalez, R. J. Harmon, S. C. Nickerson, S. P. Oliver, J. W. Pankey, and K. L. Smith. 1999. Laboratory Handbook on Bovine Mastitis. 1st ed. National Mastitis Council, Madison, WI.

Joseph, L., T. W. Gyorkos, and L. Coupal. 1995. Bayesian estimation of disease prevalence and the parameters of Diagnostic tests in the absence of a gold standard. Am. J. Epidemiol. 141:263-272.

Keefe, G. P. 1997. Streptococcus agalactiae mastitis: A review. Can. Vet. J. 38:429-437.

Koskinen, M. T., J. Holopainen, and L. Salmikivi. 2010. Field comparison of real-time PCR and conventional bacterial culturing in bovine mastitis testing. Pages 486-488 in 5th IDF Mastitis Conf. Proc.: Mastitis Research Into Practice, Christchurch, NZ. Dunmore Publishing Ltd., Wellington, New Zealand.
Makovec, J. A., and P. L. Ruegg. 2003. Results of milk samples submitted for microbiological examination in Wisconsin from 1994 to 2001. J. Dairy Sci. 86:3466-3472.

NCDF (National Cohort of Dairy Farms). 2009. 2009 National Cohort of Dairy Farms (NCDF). National Cohort of Dairy Farms reference manual. Accessed May 28, 2012. http://www.mastitisnetwork.org.

National Mastitis Council. 2004. Microbiological Procedures for the Diagnosis of Bovine Udder Infection and Determination of Milk Quality. 4th ed. National Mastitis Council, Madison, WI.

Olde Riekerink, R. G. M., H. W. Barkema, D. F. Kelton, and D. T. Scholl. 2008. Incidence rate of clinical mastitis on Canadian dairy farms. J. Dairy Sci. 91:1366-1377.

Phuektes, P., P. D. Mansell, and G. F. Browning. 2001. Multiplex polymerase chain reaction assay for simultaneous detection of Staphylococcus aureus and streptococcal causes of bovine mastitis. J. Dairy Sci. 84:1140-1148.

Plummer, M. 2003. JAGS: A program for analysis of Bayesian graphical models using Gibbs sampling. Proceedings of the 3rd International Workshop on Distributed Statistical Computing, Vienna, Austria. K. Hornik, F. Leisch, and A. Zeileis, ed.

R Development Core Team. 2009. R: A language and environment for statistical computing. R Foundation for Statistical Computing, Vienna, Austria. Accessed May 2011. http://www.r-project.org.

Reyher, K. K., S. Dufour, H. W. Barkema, L. Des Côteaux, T. J DeVries, I. R. Dohoo, G. P. Keefe, J.-P. Roy, and D. T. Scholl. 2011. The National Cohort of Dairy Farms - A data collection platform for mastitis research in Canada. J. Dairy Sci. 94:16161626

Sears, P. M., and K. K. McCarthy. 2003. Diagnosis of mastitis for therapy decisions. Vet. Clin. North Am. Food Anim. Pract. 19:93-108.

Sears, P. M., B. S. Smith, P. B. English, P. S. Herer, and R. N. Gonzalez. 1990. Shedding pattern of Staphylococcus aureus from bovine intramammary infections. J. Dairy Sci. 73:2785-2789.

Taponen, S., L. Salmikivi, H. Simojoki, M. T. Koskinen, and S. Pyörälä. 2009. Real-time polymerase chain reaction-based identification of bacteria in milk samples from bovine clinical mastitis with no growth in conventional culturing. J. Dairy Sci. 92:26102617

Viguier, C., S. Arora, N. Gilmartin, K. Welbeck, and R. O'Kennedy. 2009. Mastitis detection: Current trends and future perspectives. Trends Biotechnol. 27:486-493.

Wellenberg, G. J., O. C. Sampimon, A. Rothkamp, W. A. van Haeringen, and T. J. G. M. Lam. 2010. Detection of mastitis pathogens by real-time PCR in clinical and subclinical samples. Pages 539-544 in 5th IDF Mastitis Conf. Proc.: Mastitis Research Into Practice, Christchurch, NZ. Dunmore Publishing Ltd., Wellington, New Zealand.

Wichmann, B. A., and I. D. Hill. 1983. An efficient and portable pseudo-random number generator. J. R. Stat. Soc. Ser. C Appl. Stat. $31: 188-190$

Wilson, I. G. 1997. Inhibition and facilitation of nucleic acid amplification. Appl. Environ. Microbiol. 63:3741-3751. 